\title{
(i)
}

This work is licensed under a Creative Commons Attribution 4.0 International License

https://creativecommons.org/licenses/by/4.0/

https://doi.org/10.24833/2687-0126-2021-3-1-10-26

\section{SEACRAFT NAMES IN MILITARY DISCOURSE}

\author{
Ekaterina Golubkova \\ katemg@yandex.ru \\ Ekaterina Kivileva \\ kivilevakate@mail.ru \\ Moscow State Linguistic University (Moscow, Russia)
}

\begin{abstract}
The article analyses the process of meaning formation of names of warships in the military discourse with the aim of identifying conceptual mechanisms which underlie the naming of seacraft. The research constitutes part of the study in the field of cognitive linguistics and fills in the gap in the studies of metaphoric potential and cultural specificities of secondary names applied to artifacts (as big as warships) in British and American tradition. The results show that of all 1200 seacraft names, 700 units are originally zoomorphic common nouns transformed into proper names of seacraft with which they "share" and sometimes even exchange some of their basic or latent semantic characteristics. It was revealed that underlying mechanisms of meaning formation in seacraft nicknames are cognitive mechanisms of conceptual metaphor, focusing and defocusing. To describe them the methods of frame analysis and cognitive metaphoric modelling are employed. Metaphor in the paper is both the object and the tool of research. To support the analysis, the information about specific features of named objects and creatures is elicited from dictionaries and language corpora.
\end{abstract}

Key words: Cognitive linguistics, military discourse, conceptual metaphor, focusing, defocusing, secondary nomination

How to cite this article: Golubkova E.E. \& Kivileva E.B. (2021). Seacraft Names in Military Discourse. Professional Discourse \& Communication, 3(1), pp. 10-26. (in Russian). https:// doi.org/10.24833/2687-0126-2021-3-1-10-26

\section{INTRODUCTION}

I

$\mathrm{n}$ cognitive linguistics, there are several issues that may be legitimately raised concerning the mechanism of naming. The so-called secondary names of artifacts, in particular, seem

to be symptomatic of the cognitive mechanisms involved in naming, as they explicitly reflect the processes of categorization and conceptualization. The paper relies on the methods currently applied in cognitive linguistic paradigm and is devoted to the issue of correspondence between language expressions and their mental representations (see works by E.S. Kubryakova, N.N. Boldyrev, V.Z. Demjankov, V.I. Zabotkina, O.K. Iriskhanova, E. G. Beljaevskaya, A. Wierzbicka, R.W. Langacker, M. Johnson, Ch. Fillmore, J. Lakoff, E. Rosch, L. Talmy and others). 
Cognitive linguistic research of secondary nomination typically points out such essential blocks of meaning construction as conceptual metaphor and conceptual metonymy [Lakoff \& Johnson, 1980], focusing and defocusing [Iriskhanova, 2014; Belyaevskaya, 2013], conceptual semantics [Jackendoff, 1984], categorisation and prototypes [Rosch, 1983; Lakoff, 1993; Taylor, 1995], frame semantics [Fillmore, 1976], image schemas, etc. Researchers seek to underpin conclusions by a whole set of examples of empirical data typically drawn from linguistic corpora [Gibbs, 1996; Golubkova, 2011; 2020]. Equipped with these tools of research we set out to explore some specific features of cognitive mechanisms engaged in the process of secondary nomination and study the semantics of secondary names - seacraft names in British and American cultural traditions.

Though secondary nomination tends to be in the focus of linguistic studies, the naming potential of conceptual metaphor is usually beyond the scope of research. Explorers in the field of nomination analyse formal and informal names [Rodina, 2014; Ermolovitch, 2001; Romanov, 2000], while we attempt to study metaphorised common nouns functioning as names and nicknames. It is noteworthy that conceptualisation (and categorisation) through language means is more conspicuous in proper names of all kinds, especially former common nouns.

Conceptual metaphor is a means of representation and modification of experience at large. Metaphors help interpret reality both subjectively and objectively. In terms of J. Lakoff secondary metaphorical nomination is constructed upon the perception of one conceptual domain in terms of another on the basis of several characteristics [Lakoff \&Johnson, 1980; Boldyrev, 2013] of the source-domain. Then the chosen feature (Talmy's figure, Jackendoff's focus, Langacker's profile or trajector) is projected on to the target-domain. The choice of the features is seen as centered on focusing [Lakoff, 1993; Taylor, 1995; Fillmore, 1985; Iriskhanova, 2014]. The material of more than 700 navy vessels' metaphorical names with animalistic motivation shows that in seacraft nomination one type of conceptual metaphor stands out. It can be described as the animalistic conceptual metaphor that initiates formation of new names in line with metonymy, stereotyping, de-/focusing and other cognitive mechanisms. The animalistic conceptual metaphor appears as the foundation of different name types including official names, non-official nicks, code-names and the like.

A secondary name just like an alias is supposed to be the so-called visualiser. Replacing lengthy descriptions and wordiness with pictures, memes, and videocasts is as inherent in the modern discourse as it belongs in the times of the budding civilization with cave pictures later translated into signs. Bringing in the spotlight the historical process of metaphorical naming and new ways of expression such verbal visualisers are the reflection of both tradition and innovation in the navy discourse.

\section{MATERIAL AND METHODS}

Thus, units of specialized discourse nowadays increasingly become the object of study of the nomination theory. In particular, non-official nicknames of animalistic origin functioning in the military discourse seem to be the secondary naming units whose 'recycled' use can shed light on the internal processes underlying secondary nomination patterns. The research is carried out within the framework of cognitive linguistic approach, which exploits a set of research tools to describe any process of deliberate and non-deliberate nomination. Preliminary research shows that the process of nicknaming seacraft relies on the correlation between metaphorical concepts and 
metaphorical expressions, the study of which may reveal other cognitive-nominative mechanisms which come into play in the process of naming.

In the paper we set the aim to identify ways of elaboration of animalistic conceptual metaphor on which the naming of the seacraft is based. While pursuing this aim we will be looking into the following research questions:

- the meaning formation and the visualising potential of metaphorical names;

- the prevalence and reasons for animalistic names among warships;

- the specificity of British and American seacraft naming traditions;

- the possible connection between metaphor and other cognitive mechanisms underpinning naming in the military discourse.

Among the methods employed we rely on the method of cognitive modelling of the meaning on the basis of the theory of metaphor [Goossens, L. \& Pauwels, P. \& Rudzka-Ostyn, B. \& Simon-Vandenbergen, A.-M. \& Vanparys, J., 1995; Lakoff, 1993; Leezenberg, 1995] where metaphor can become a tool of analysis. Conceptual metaphor is an instrument of exploring projections and mappings between the source and the target in the secondary nomination process. We also resort to the method of frame analysis [Charniak, 1982; Belyaevskaya, 2012] comparing the main characteristics of animals represented by the neutral and expressive slots of the frame LIVING BEING with the basic technical characteristics of ships as seen by the name-creator.

The use of such language corpora as BNC (British National Corpus), COCA (Corpus of contemporary American English), 'НКРЯ' (Национальный корпус русского языка - National Corpus of the Russian Language) enables us to set optimal parameters and study contexts of word usage with the aid of modern technologies [Evans \& Chilton, 2010; Golubkova, 2012; Suvorina, 2015; Finegan, 2011; Smith, Hoffmann \& Rayson, 2008; Stefanowitsch, 2006]. The approach makes it possible to trace the contextual and situational semantic changes of zoomorphic nouns denoting ships.

\section{ANALYSING THE PROCESS OF NAMING IN WARSHIPS}

\subsection{History of naming warships}

Before focusing on the semantics of zoomorphic names we consider it important to pay attention to the naming traditions in the navy which constitute the extralinguistic nomination guidelines. Interestingly, naming seacraft is a responsibility often taken up by either the ship constructor, the captain or the crew in the battle, or sometimes by the enemy who observes the vessel in action. A ship without a name is viewed as a failure like an unbaptized child. From century to century, it has been referred to as vulnerable, unsafe and doomed. Very often, the choice of name is a matter of superstition, an attempt to deceive and outwit destiny, a wish to scare misfortunes away. Any vessel should necessarily have a number and an official name, while non-official names or nicks turn out to be a long-standing tradition, complying with national and international nominative strategies of the military discourse.

The history of ship names vividly reflects the history, the epoch, the policy or politics of the country of origin, predominant tendencies or traditions. Ancient tales, legends and myths still preserve the names of ships famous for great deeds and fantastic battles [Kalanov, 2020]: the Egyptian Pharaohs' vessels "Wild Bull", the Vikings' "Great Aurochs", the Greek "Argo", and the Russian "Falcon". The age of Great Explorations is characterized by the fame of Spanish and Portuguese ships named in the traditions of the Middle Ages in honour of God after the divine protectors of 
seamen and other saints, such as Vasco Da Gama's "Saint Gabriel" and "Saint Rafael", Fernando Magellan's "Saint Antonio", "Trinity", "Saint Jacob", "Conception". In the $16^{\text {th }}$ and $17^{\text {th }}$ centuries, Pirate Armadas ruled the seas amid the naval rivalry between Spain, Britain, France and the Netherlands (at that time - Holland). Daring O'Reilly, Francis Drake and Henry Morgan sailed the seas on "The Destiny", "The Golden Hind", "The Roebuck", and "The Rainbow".

In the mid-1 $18^{\text {th }}$ century, there appeared a tradition of naming vessels of scientific expeditions and thereby indicating the aim of the voyage: "The Investigator", "The Hope", and "The Search". The expressive and emotional names of polar expeditions reflected expectation, fear, danger, determination, and resistance: "The Terror", "The Confidence", and "The Victory". By the early $20^{\text {th }}$ century, most of the usual ship names had been gradually supplanted by those denoting national or geographical factors: "The Scotia", "The Belgica", "The France", "The Dana", etc. Names of islands, countries, emperors, presidents, ministers, bankers as well, marked important people or events of the moment. The centuries-old history of the navy contributed to the appearance of ships' dynasties: British "Discovery" has been known since 1602; American "Challenger" dates back to 1872.

Launching focus on the process of categorisation by means of language units we hold that naming in specialized discourse tends to be targeted at specific goals. Secondary nomination of seacraft is based on metaphorical comparison between animals and ships, in other words, it is "visually motivated". Seacraft's names represent cases of semantic derivation that owe part of their meaning to some object or source. For example, if a ship is dubbed as "MEDOWLARK", we are likely to get a conceptual link to the peaceful image of a bird flying over the meadow, no matter how unexpected and illogical this navy name may seem to an outsider. The common noun (in this case the compound of two common nouns) transforms into a proper noun and designates a vessel still preserving a reference to its original sphere of application (nature, wildlife). Besides, when we visualise a bird's name on military machinery the name itself seems to acquire a military connotation as if wearing war paint. This is a very unusual exchange of features between seacraft and animated objects, which explains why a set of associations and stereotypes are ascribed to a secondary ship name. Likewise, there is obviously a visual link between the name and the named ship.

\subsection{Types of designation of military seacraft}

While analyzing the corpus of material we traced a whole plethora of names attached to the same vessel. It is accounted for by historical and practical reasons, i.e. it was advised in the past and is recommended today that a ship should receive a formal designator (name (+ number)) while being commissioned in order to be registered. This official name, according to the data supplied, could change with time to meet the new requirements of the navy or to reflect the historical, political or social changes. One more element of designation is represented by a nickname - an unofficial name serving as a supplementary naming device in case the official name is not welcomed by the crew (it can be considered dissonant, bulky, ambiguous, etc.) or not known. Nicks do not undergo any formal procedure of registration and can be spontaneously given to a vessel by the personnel or even by the opposing forces in the course of combat action in order to praise or diminish its characteristics.

Both regular secondary names of British and American warships and nicknames along with other types of designation are typically expressive and emotionally-charged, including the following:

1) Emblem or/and a moto: "Audaces fortuna juvat", "Spirit of ' 76 ", "Tough, determined, ready to lead", "Seek and destroy", "Per mare per terram", "Tough, determined, ready to lead" (Table 1): 
Table 1. British and American warships' emblems.

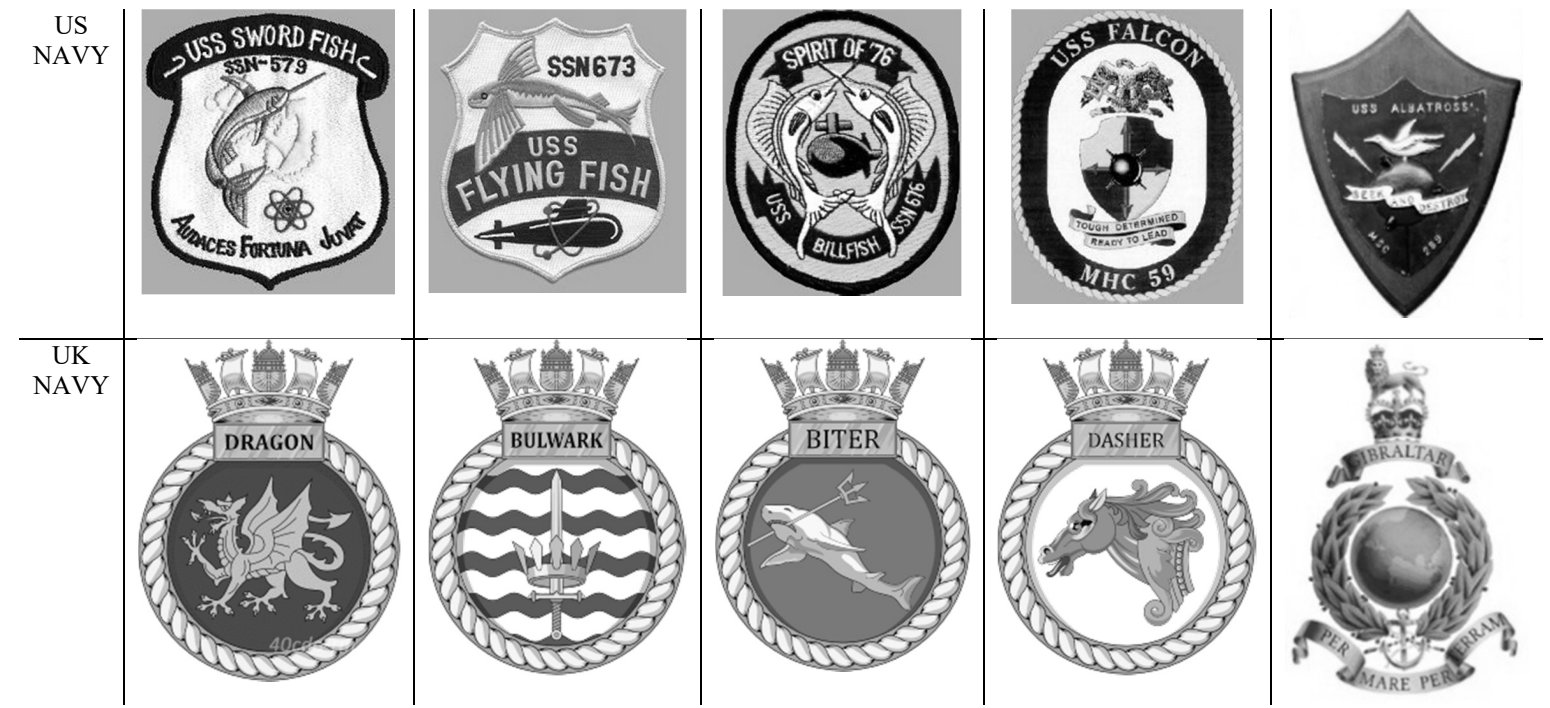

2) A number or a letter designation: TB.025-079 (originally 25-79), 81-87; A.5, submarine, A-class, I.15; USAT LST-833; USAT Y-17.

3) Official name that is usually borrowed from a domain, for example the domain of animal world (Table 2):

Table 2. Examples of names of ship classes and ships.

\begin{tabular}{|c|c|c|c|c|} 
Archer class & Greyhound class & Skate class & \multicolumn{2}{|c|}{ USA } \\
torpedo cruisers & destroyers & submarines & \multicolumn{2}{|c|}{ Beagle class (G) destroyers } \\
Archer & Greyhound & Skate & Basilisk & Pincher \\
Mohawk & Racehorse & Swordfish & Beagle & Renard \\
Brisk & Roebuck & Sargo & Bulldog & Racoon \\
Porpoise & & Seadragon & Foxhound & Rattlesnake \\
Cossack & & & Harpy & Savage \\
Tartar & & & Grasshopper & Scorpion \\
Serpent & & & Mosquito & Scourge \\
Racoon & & & Nautilus & Wolverine
\end{tabular}

The name goes with the abbreviation HMS (Her/His Majesty Ship) or USS/USAT (United States Ship или United States Army Transport).

4) Code-name can be given to a national navy ship when it participates in secret missions or to a foreign navy ship: Britain's STALLION, PYTHON, CYGNUS, DUCK, FERRET, FROG, PUSSYFOOT; America's BATTLE CAT, GOLD EAGLE.

5) Non-official name/nickname:

$\begin{array}{ll}\text { Name } & \text { Nickname } \\ \text { HMS WARSPITE } & \text { "Old Lady" } \\ \text { USS KITTYHAWK } & \text { "Shitty-kitty" } \\ \text { USS VALLEY FORGE } & \text { "Happy valley" } \\ \text { USS CAMPBELL } & \text { "Soup Can" }\end{array}$



USS NAUSHON
USS ENTERPRISE
HMS MALLOW

Each type of designations listed above performs different functions denoting and foregrounding different aspects of seacraft's functioning. The names are motivated, most of them are meant to sound inspiring. Thus, nomination of warships owns a specific character of motivation. Motivation is internal when there is some visible similarity between an animal and a vessel, that is, appearance, habits or lifestyle of the former and the technical characteristics of the latter. Motivation is external when the name is given by tradition or analogy in compliance with the formal procedure of naming ships. Specific analogies exist within this or that ship class or dynasty.

\subsection{Secondary nomination of warships and its rules}

It is quite common for military discourse to use common lexis in a codified fashion. Thus, animalistic items being used as part of an offensive, a form of disguise or camouflage that seek to intimidate the opposite side, mask real intentions or prove a point. Names are selected on the basis of the relevant visualising focus idea - the most vivid one - expressed in the shortest version possible. Simplicity and brevity are as critical for the military discourse as they are for the names used in it: both official (BUFFALO, HAWK, RAVON, SNAKE), and non-official ones (COW'S LIP, MUD DUCK, CHICKENFEED, VIG THE PIG). The informal names take root in the slang names of the navy and army personnel and military equipment: devil dog (sailor), camel corps (infantry), land crab (military police officer), bird of paradise/goose/duck (colonel), chick (recruit), warhorse (veteran); rat-trap (submarine), whale/tin fish (torpedo), grasshopper/whirlybird (helicopter), seadog (gun), iron horse (tank) [Lisov \& Solodun, 2014].

Usage frequency of zoomorphic lexis demonstrates close associative ties between military realities and the animal world. Though the navy/army is a close-knit institution, there is wiggle room for expressing one's position - in this case through animalistic metaphorical nomination. With respect to nicks, they appear to reflect characteristics of secondary nomination of an artefact: evaluation, multifunctional character, markedness, which makes a ship name close to a personal social account name or a chat name that visualises its owner while individualising or collectivising them.

Interestingly, military lexis denoting types of armaments, names of artefacts, arsenals is massively discussed online in chats, social networks and games [http://www.shipsnostalgia.com/forumdisplay.php?f=310], [http://navyformoms. com/forum], [http://forum.warthunder.com/index. php?/forum/495-naval-discussion/], which makes the military language means popularised and "alienated" from their natural context. That seems to be one of the functions of metaphorical nomination - to explain something specifically terminological to a wider audience in the natural process of visualising through naming. The process of metaphorisation makes images accessible and understandable, memorable and concise.

The analysis of names of artefacts in the military discourse proves that secondary nomination of warships reveals certain regularities [Kivileva, 2017]:

1. Ambiguity. Identical names of ships can belong to different types, generations and classes within the same navy group, for example: PHOENIX, ALBATROSS, DRAGON, FALCON, DOLPHIN, BLUEBIRD. Thus, PHOENIX is used to designate British frigates, destroyers, submarines, etc.

2. Uneven distribution. Secondary names are distributed unevenly between ship classes and navies owing to extralinguistic considerations (Table 3). 
Table 3. Unevenness of ship names distribution.

\begin{tabular}{|c|c|c|}
\hline Ship class & $\begin{array}{l}\text { UK (\% of animalistic names of } \\
\text { the total number of names) }\end{array}$ & $\begin{array}{l}\text { USA (\% of animalistic names of } \\
\text { the total number of names) }\end{array}$ \\
\hline Destroyer & 23 & 3 \\
\hline Aircraft carrier, seaplane carrier, seaplane tender & 2,6 & 2,7 \\
\hline Minesweeper, minehunter, hired trawler/drifter & 4,6 & 21 \\
\hline $\begin{array}{l}\text { Cruisers: light cruiser, armoured cruiser, battlecruiser, torpedo } \\
\text { cruiser }\end{array}$ & 4 & 3 \\
\hline Submarine & 3 & 35,5 \\
\hline Minelayer & 0,2 & 0,5 \\
\hline Patrol vessel, patrol boat, patrol craft, hired patrol tug & 1,8 & 13 \\
\hline Gunboat & 14 & 8 \\
\hline Schooner & 0,4 & 3 \\
\hline Torpedo boat & 0,5 & 0,5 \\
\hline $\begin{array}{l}\text { Sloop of war, brig-sloop, ship-sloop, torpedo sloop, fleet sweeping } \\
\text { sloop, brig-corvette, gun-brig }\end{array}$ & 14 & 2 \\
\hline Survey ship, survey vessel & 1,5 & 0,5 \\
\hline Frigate, anti-aircraft frigate, armoured frigate, guided missile frigate & 12 & 0,5 \\
\hline Ship of the line, battleship, turret ship & 7 & - \\
\hline $\begin{array}{l}\text { Combat storeship, flotilla supply ship, mine carrier, submarine } \\
\text { tender }\end{array}$ & 2 & 0,5 \\
\hline Bomb vessel, mortar vessel & 1,8 & - \\
\hline Boom defence vessel, hired trawler/drifter & 0,8 & - \\
\hline Flyboat, auxiliary vessel & 0,7 & - \\
\hline Coastal anti-submarine escort, whaler & 0,4 & - \\
\hline Harbour defence vessel & 0,5 & 0,5 \\
\hline Depot ship, auxiliary ship & 0,7 & - \\
\hline Floating battery & 0,5 & - \\
\hline Rescue tug, hired screw/dockyard tug & 1,8 & 0,5 \\
\hline Submarine rescue ship & - & 1,6 \\
\hline Destroyer tender, auxiliary ship & - & 1 \\
\hline Monitor ship & - & 0,5 \\
\hline Landing ship, amphibious assault ship & - & 1 \\
\hline Q-ship & - & 0,5 \\
\hline Reconnaissance vessel, research vessel & - & 1 \\
\hline Ram steamer & - & 0,5 \\
\hline Cargo ship & - & 1,6 \\
\hline Hydrofoil & - & 0,5 \\
\hline Victory ship & - & 0,5 \\
\hline
\end{tabular}

3. Logic. There is certain dependence between the classes of ships and the choice of naming options from different animal classes and types. The assault ships typically get the names of aggressive "assault" animals, usually predators.

4. Change. Renaming takes place due to pragmatic and military-historical reasons: DOVE KANGAROO, HERMES - ELEPHANT, NAUTILUS - GRAMPUS; NEW UNCLE SAM BLACK HAWK, HOUQUA - BLUE BIRD, CUTTLEFISH - B2.

5. Animal world domain. The domain of the animal world is among many other source-domains. Each animalistic item has a collection of more or less prototypical features [Rosch, 1983; Taylor, 1995] that can be figuratively exploited. Though names of animals are typically monosemantic, they are deeply connoted, being either culturally universal or culturally specific. Secondary nomination involving names of animals as names of warships mainly encompasses such zoomorphic names that could hint at some feature or symbolize a characteristic. The universal nominative trends in the conceptual domain MILITARY ARTEFACTS are biased in favour of predatory animals associated with aggressive behaviour, large size, and speed. 
6. Ideology. Metaphorical naval nomination serves ideological and strategic aims indicated by the frequency of use of names of dangerous wild animals like USS PANTHER, USS SCORPION, USS TIGER, HMS LEOPARD, and HMS ALLIGATOR. It is possible that naming reflects the major directions of foreign policy pursued by a state in the given period of history. Referring to the conceptual content of animalistic names, we can see their symbolic value and a political coloration. For instance, in the eyes of European and American speakers DOVE, HAWK, DONKEY, ELEPHANT seem to carry additional connotational workload. Metaphorically DOVE and HAWK stand for the opponents and proponents of political solution to a conflict respectively, while DONKEY and ELEPHANT symbolise the two major political parties in the US.

\subsection{Metaphorical zoomorphic images in navy nomination}

As it follows from the abovementioned features of zoomorphic seacraft names, the experience of human interaction with animals is transmitted from generation to generation in the form of unique or common knowledge. The past experience and conceptual information help to interpret, categorise, identify, and recognise an object [Evans, 2010]. Embodied experience is translated into image-schemas (also referred to as concepts) [Lakoff, 1987, 1993; Evans, 2010; Merleau-Ponty, 1967] - mental representations of objects and means of expressing this experience at the cognitive level, at the same time conceptual building blocks of nomination. While communicating with animals a child gets to learn the world around in the form of partially embodied experience which is not yet conceptual. This can account for the rooted link between images of animals with stereotypes and connotations in the human cognitive system. This experience initiates the structures of knowledge that teach us the ability to predict common outcomes of behavioral scenarios. From abstract image-schemas there appear more complex and detailed mental images and representations (also - lexical concepts) [Evans, 2010; 2013]. Primary image-schemas arise from live communication, e.g. a child while communicating with a cat draws their first conclusions about the cat's habits and the main characteristics that differentiate the cat from other animals or objects. These direct and indirect contacts allow forming understanding of such qualities and processes of objective reality as "soft", "sharp", "fluffy", "the cat purrs", "the cat can scratch", etc. Further generalizations about animalistic characters derive from this primary understanding. The knowledge we get enables us to determine which similarities and differences between source and target domains are reflected in the zoomorphic names.

Thus, sharing the viewpoint of a number of cognitive linguists, we believe that metaphors underlying nicknames in the military discourse emerge as a result of perceiving some similarity between what has been experienced and what is emerging, but yet unnamed. Speakers see a correlation between two objects as part of the visualisation process aimed at schematising a concept into a target domain [Kövecses, 2008; 2010].

As is known, in cognitive studies metaphor is a conceptual phenomenon, a means of conceptualising abstract or unknown spheres in terms of concrete or familiar ones [Lakoff \& Johnson, 1980; Lakoff, 1987; Feyaerts, 2000; Rakova, 2003]. The metaphor actualised in names of seacraft and dictated by the tradition of animalistic naming trends can be summed up as VESSEL IS ANIMAL. Interpreting the secondary nomination of military vessels on the basis of Fillmore's frame semantics [Fillmore, 1985] we perceive animalistic names as frames with slots, some of which get focused on in mappings between the source and the target domains. Slots are prototypical characteristics of animals eliciting the most frequent, that is, typical traits deduced from comparison of dictionary definitions. In the frame ANIMAL slots include information about the size, form, body, colour, sound, smell, movement, habitat, character traits, interaction, life expectancy, additional 
information. The frame ANIMAL can be seen as a varietal way of representing the generic metaphorical concept LIVING BEING, schematically presented below:

\section{Scheme 1. Metaphorical concept LIVING BEING}

SENSE ORGANS

THINKING

LIVING BEING

RESPONSE TO

STIMULI

The metaphoric concept LIVING BEING can be described through 4 major characteristics above, each of which is realized via concrete indicators. Indicators of living beings as slots of the LIVING BEING frame or more concrete frames ANIMAL, BIRD, FISH, and INSECT are given below:

Scheme 2. Slots of the frame LIVING BEING

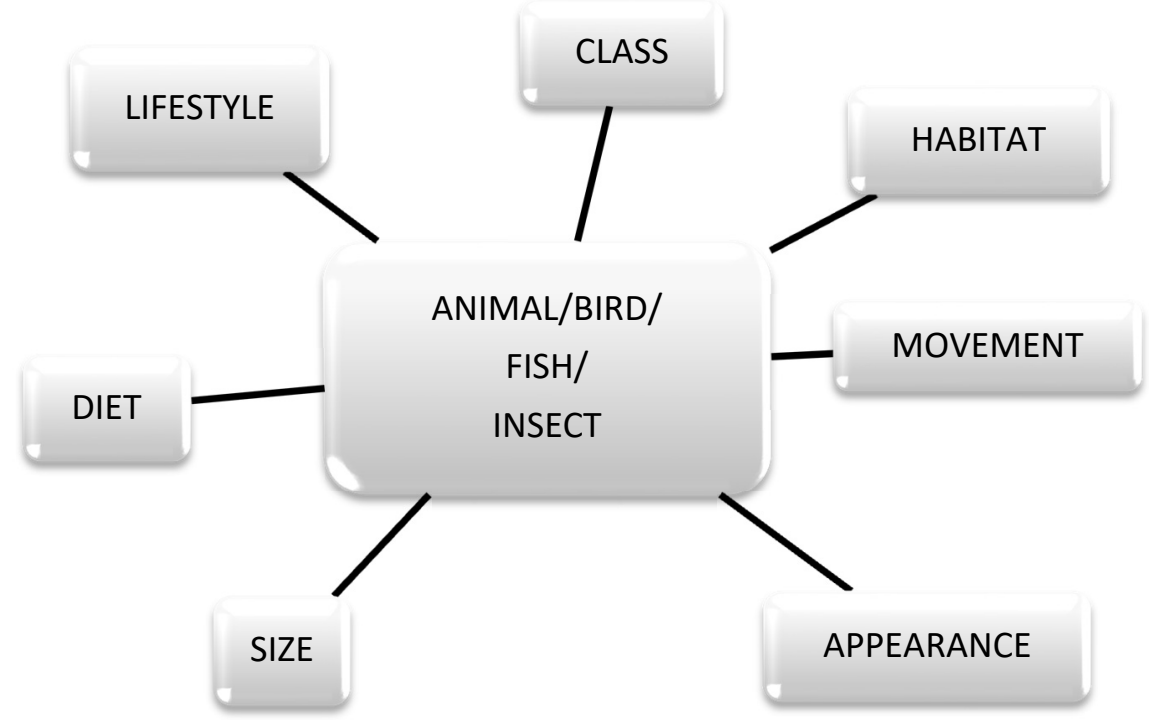


Each slot of the frame LIVING BEING can be metaphorized and can also participate in mappings between domains WARSHIPS and ANIMAL WORLD. Slots of these two frames ANIMAL and WARSHIP can be found in comparison in the table below. We analyze frames ANIMAL and WARSHIP by six most common indicators that can vary with the shift of the nominative focus.

\section{Table 4. Slots of frames ANIMAL and WARSHIP compared}

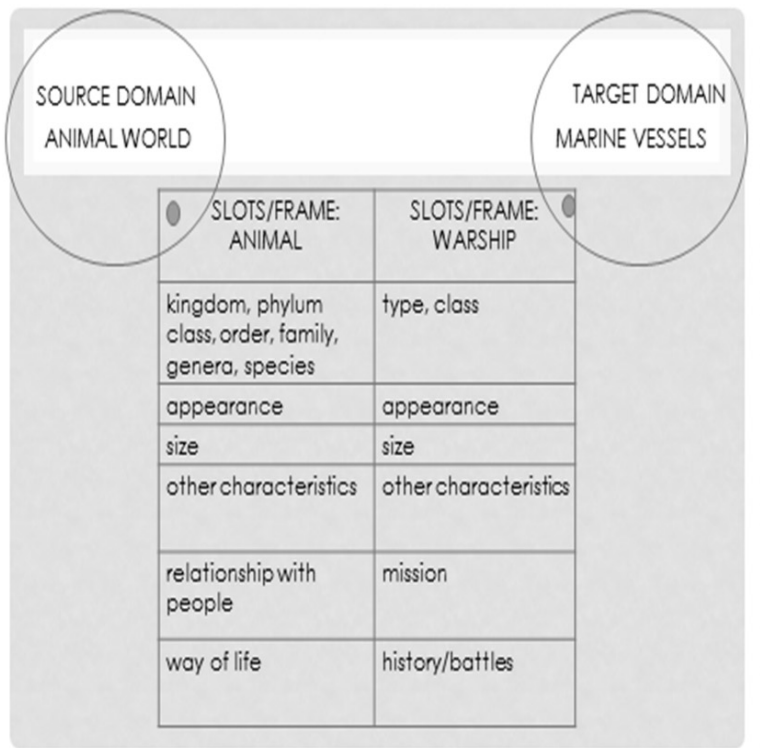

\begin{tabular}{|c|c|c|}
\hline \multicolumn{2}{|l|}{$\begin{array}{r}\text { SOURCE DOMAIN } \\
\text { ANIMAL WORLD }\end{array}$} & $\begin{array}{l}\text { TARGET DOMAIN } \\
\text { MARINE VESSELS }\end{array}$ \\
\hline $\begin{array}{l}\text { SLOTS/FRAME: } \\
\text { BEAR }\end{array}$ & $\begin{array}{l}\text { Base of mappings } \\
\text { between domains: }\end{array}$ & $\begin{array}{l}\text { SLOTS/FRAME: } \\
\text { WARSHIP }\end{array}$ \\
\hline $\begin{array}{l}\text { mammal, dog fomily, } \\
\text { omnivorous }\end{array}$ & \multirow{6}{*}{$\begin{array}{c}\text { Way of hunting } \\
\text { Heovy fur } \\
\text { Size } \\
\text { Symbolism }\end{array}$} & $\begin{array}{l}\text { WMEC- } 901 \text {, steam cutter, } \\
\text { patrol vessel }\end{array}$ \\
\hline heovy, with thickfur & & $\begin{array}{l}\text { ice strengthened, } 1 \\
\text { funnel, } 3 \text { masts }\end{array}$ \\
\hline large & & length $198.5 \mathrm{ft}(60.5 \mathrm{~m})$ \\
\hline $\begin{array}{l}\text { specific walking manner, } \\
\text { associated with a rude ill- } \\
\text { bred person, symbol of evil } \\
\text { and cruelty }\end{array}$ & & $\begin{array}{l}703 \text { tons displacement, } \\
\text { auxiliary service }\end{array}$ \\
\hline training, protecting, hunting & & $\begin{array}{l}\text { coast guard, whaler, } \\
\text { sealer }\end{array}$ \\
\hline $\begin{array}{l}\text { fishing, feeding on berries, } \\
\text { plant roots and shoots, } \\
\text { small mommals, calves of } \\
\text { many hoofed animals and } \\
\text { corrion, retire to dens in } \\
\text { winter }\end{array}$ & & $\begin{array}{l}\text { lounched } 1874 \text {, from } 1941 \\
\text { to } 1944 \text { served in the } \\
\text { Northeast Atlantic } \\
\text { Greenland Patrol }\end{array}$ \\
\hline
\end{tabular}

Metaphorisation is achieved on the basis of similarity, even though sometimes similarity has to be created rather arbitrarily [Leezenberg, 1995; Belyaevskaya, 2013]. For instance, conceptual metaphor WARSHIP IS A BEAR means that a warship does not actually resemble a bear but is conceptualized as a bear, it is based on discovering similar characteristics between domains MARINE VESSELS and ANIMAL WORLD. This process relies on human mind's creativity, imagination, fantasy, subjective and objective logic.

Thus, metaphor brings together two different objects, ideas, actions that simultaneously come to mind through mappings between domains [Galperin, 1981]. Metaphor unfolds as part of categorisation of objective reality. Based on similarity it creates images of the world around, compares them with personal experience, verifies or falsifies them providing for abstract thinking.

Interestingly, metaphoric images in warship names are «truth-value free» [Hausman, 1989] as they exist beyond the frames of true-false evaluation. Metaphor itself categorises and describes new referents, for example, when it gives a destroyer an unusual name, like CYGNET, LARK or GRASSHOPPER. Before becoming part of the metaphorisation process both the target domain (MARINE VESSELS) and the source-domain (ANIMAL WORLD) used to have independent structures. Metaphoric mappings can help disclose (or even create similarities) and construct shared space between them [Indurkhya, 1992]. For example, names of British and American submarines vary in the conceptual domain ANIMAL WORLD from dangerous animals (SCORPION, SKATE, SHARK, BUFFALO) to relatively harmless ones that at first sight have little in common with military artefacts (OTTER, SEAHORSE, SEAL, OPOSSUM, STARFISH, SALMON, TRITON). Therefore, along with creativity metaphor sets its own parameters of credibility and relevance. Animal names assume a new "tone" or connotation when transformed into names of submarines, aircraft carriers or minesweepers: this is the visualised animalisation of characteristics 
of seacraft in metaphorical comparison with prototypical features of animals in focus or out of focus, if necessary.

Examples show correlations existing between structures of various frames. Thus, the name SNAKE referring to the concept SNAKE activates and projects onto the artefact universal snake characteristics or slots of the frame SNAKE (Model 1) (fear, response, threat) that can simultaneously be slots of another frame - THREATENING SITUATION (Model 2):

Model 1. Structure of frame THREATENING SITUATION

\begin{tabular}{|c|c|c|}
\hline $\begin{array}{c}\text { threat } \\
\text { (real, expected, imaginable, etc.) }\end{array}$ & fear & response \\
\end{tabular}

\section{Model 2. Structure of frame SNAKE}

\begin{tabular}{|c|c|c|c|c|c|}
\hline \multirow{6}{*}{$\begin{array}{l}\text { class, } \\
\text { type, } \\
\text { family }\end{array}$} & specific appearance & \multirow{6}{*}{$\begin{array}{c}\text { strong } \\
\text { dangerous } \\
\text { long } \\
\text { invisible } \\
\text { sly } \\
\text { invincible } \\
\text { malicious } \\
\text { rapid }\end{array}$} & \multirow{6}{*}{$\begin{array}{c}\text { threat } \\
\text { (attack, } \\
\text { strangle, } \\
\text { bite, etc.) }\end{array}$} & \multirow{6}{*}{ fear } & \multirow{6}{*}{$\begin{array}{l}\text { response } \\
\text { (hide, } \\
\text { drive away, } \\
\text { defend, } \\
\text { deceive) }\end{array}$} \\
\hline & strength & & & & \\
\hline & size, length & & & & \\
\hline & poison/no poison & & & & \\
\hline & quick reaction & & & & \\
\hline & stereotyped character & & & & \\
\hline
\end{tabular}

Models show that the frame SNAKE can be recognised as a hyponym of the hyperonymic frame THREATENING SITUATION. Besides, the structure of the frame SNAKE shows the same slots as the structure of the frame WARSHIP (Model 3) that can also be viewed as a hyponym of the frame THREATENING SITUATION.

\section{Model 3. Structure of frame WARSHIP}

\begin{tabular}{|c|c|c|c|c|c|}
\hline \multirow{5}{*}{$\begin{array}{l}\text { war } \\
\text { class, } \\
\text { type }\end{array}$} & specific appearance & \multirow{5}{*}{$\begin{array}{c}\text { large } \\
\text { dangerous } \\
\text { oblong } \\
\text { streamlined } \\
\text { attacking } \\
\text { defending }\end{array}$} & \multirow{5}{*}{$\begin{array}{c}\text { threat } \\
\text { (fire, intimidate, etc.) }\end{array}$} & \multirow{5}{*}{ fear } & \multirow{5}{*}{$\begin{array}{c}\text { response } \\
\text { (hide, drive away, } \\
\text { defend, deceive) }\end{array}$} \\
\hline & combat characteristics & & & & \\
\hline & size, length & & & & \\
\hline & guns/no guns & & & & \\
\hline & rapid action & & & & \\
\hline
\end{tabular}

The frame analysis proves that similar slots and shared images are the foundations of the metaphorical comparison and analogy between the frames ANIMAL and WARSHIP and of the conceptual metaphor WARSHIP IS A LIVING BEING.

The analysis of animalistic seacraft names shows that the given metaphor conceptualises the domain MARINE VESSELS in terms of the domain ANIMAL WORLD and is activated in secondary nomination of British and American warships in the military discourse in the following most productive zoomorphic metaphorical patterns:

- $\quad$ SHIP IS AN ANIMAL

- SHIP IS A FISH

- SHIP IS AN INSECT

- SHIP IS A BIRD

- SHIP IS A SLITHERING ANIMAL

- SHIP IS A FANTASTIC CREATURE 


\section{RESULTS AND DISCUSSION. THE INTERPLAY OF CONCEPTUAL METAPHOR AND FOCUS SHIFT IN SECONDARY NOMINATION OF WARSHIPS}

As concluded above, naval naming is based on similarity found in characteristics and features of artefacts and animals. We find that some features of a concept (frame slots) are metaphorised and thus, underscored; others are viewed as less essential.

Thus, metaphorical projection is selective, in that it focuses on some characteristics of an object and defocuses others [Iriskhanova, 2014]. So, it is apparently metaphor that enables the user not only to choose, but also fix the focus of nomination in a concise and practical package for similarities found between the object and its name. The question is what the grounds are for the choice of characteristics projected between domains in the conceptual metaphor WARSHIP IS AN ANIMAL.

The analysis of examples proves that if some animalistic features are foregrounded and exaggerated, they are placed in the focus like "sense of smell" and "loyalty" in the name of the search ship BEAGLE. These qualities are used as the core projected features transformed into the generalized focus idea of secondary nomination against other features functioning as background. That is to say, the ship is praised for the searching ability and trustworthiness. Simultaneously, other animalistic features (colour, life expectancy, etc.) are backgrounded, downplayed, and shadowed. Inherently selective metaphorical projection possesses, thus, a specific focus.

This foregrounding of one of the characteristics emphasises the focus idea of the metaphorised name: resorting to animalistic frames as schematic representations of animalistic concepts, we can conclude that, for example, frame MOSQUITO places the focus on INTRUSIVENESS, frame JACKAL - on WILINESS, frame BAT - on NOCTURNAL LIFE. This focus idea can highlight either the most essential features of an object or those traits that are considered peripheral, but could become prominent because they are quite unusual or stereotyped [Kivileva, 2017]. Naturally essential features of an animal are sometimes the first to be "suppressed", while the focus of secondary nomination is placed on biologically non-essential characteristics able to create the necessary impression.

Thus, the ship name HMS FOX focuses on the sly character of the animal, whose cunning nature is still more of a folk wisdom. We find mostly examples like this in the BNC: CD9 370 Either he is as simple and as straightforward as he would like us to believe, or he is...so infinitely and deviously smart that, like a fox, he just can't be captured.

What is more, the focus idea of secondary nomination includes characteristics of objects which in terms of gestalt are able to constitute the whole impression, the whole image as seen in zoomorphic metaphorical names. For example, WHALE combines marine lifestyle and formidable size, $\mathbf{O W L}-$ hunting and night vision, PEGASUS - fantastic origin and speed, FOX - cunning character and agility, etc. In other words, we witness selection of "visually loaded" characteristics that are extremely relevant and useful in terms of nomination [Kivileva, 2017]. It is the specific, but not always transparent and clear feature that determines the motivation of the name, though.

Interestingly enough, the force of defocusing is especially palpable in the military discourse, in particular for its classified segment as part of the cryptologic branch aimed at keeping information confidential. The nature of the cognitive mechanisms of focusing/defocusing follows suit in the military discourse, where nondisclosure is the bedrock of privacy policy, and display of military might inter alia by vanity names. Defocusing is dynamic enough to conceal those features of an animal that would contradict strategic aims of secondary nomination. 
The selective character of metaphorisation defines from which angle we look at an object. In other words, metaphor defines the focus of nomination [Porokhnitskaya, 2014] and can regulate the relations of comparison in the conceptual system of a person. That is how metaphor shifts the focus in the process of secondary nomination, narrows and widens frames of perceived pictures. Thus, conceptual metaphor acts jointly with and even becomes superior to some other cognitive mechanisms, namely the bidirectional and contrasting mechanisms of focusing/defocusing [Iriskhanova, 2014].

Normally in everyday life we shift our attention intentionally and willfully seeking to focus on essential data blocks and to defocus supplementary information. Still, in secondary nomination the focus, also deliberate and goal-oriented, seems to be shifted away from essential information and on to the additional, extra knowledge as if governed more by subjective and individual purposes and wrapped in artistic design.

The metaphorically based regulation of cognitive mechanisms of focusing/defocusing in the process of secondary nomination of warships can be traced in the following examples of ships named as birds (Table $5 \&$ Table 6).

Dictionary definitions of EAGLE make the image of a great strong bird quite clear. Additional associations to support the image of its cruel and brave character are found in linguistic metaphors and comparisons in the BNC.

\section{Table 5. British warships EAGLE}

Dictionary definitions
a large bird that kills other birds and animals
for food (MacMillan Dictionary);
a very large strong bird with a beak like
a hook that eats small animals, birds etc.
(Longman Dictionary of Contemporary English);
a large bird of prey (= a bird that kills other
creatures for food) with a sharp curved beak
and very good sight (Oxford Dictionaries)

Dictionary definitions

arge bird that kills other birds and animals (MacMillan Dictionary); (Longman Dictionary of Contemporary English); creatures for food) with a sharp curved beak

\author{
British National Corpus \\ H8R 1498 Crueller than owl or eagle. \\ BNU 2110 'There's no danger,' he translated, his \\ eyes on the soothsayer's hands, 'but the boar that \\ eagle.'
}

Thus, dictionary definitions prompt the slots of the frame EAGLE that can participate in projections between domains ANIMAL WORLD and WARSHIPS and among which the most prominent are basic characteristics such as appearance and lifestyle. This slot board is conventional and culturally universal. We presume that each case of secondary nomination puts forward selectively a certain combination of characteristics borrowed from an animal or bird and assigned to a ship. That is how the ship assumes the following eagle-like qualities: predatory character, threatening appearance, power, etc. Naming the minesweeper EAGLE, we highlight and translate the searching ability of the eagle into the capacities of the ship whose mission is to find and neutralize a mine. Whereas the bird's wingspan, strength and large size are projected on to parameters and the strike force of the aircraft carrier EAGLE.

The American navy's "bird" name of choice for a range of vessels, to name a few, is HAWK:

\section{Table 6. American warships HAWK}

\section{Dictionary definitions}

a large bird that hunts and eats small birds and animals; a politician who believes in using military force $[\neq$ dove]; watch somebody like a hawk to watch someone very carefully (Longman Dictionary of Contemporary English);

a diurnal bird of prey with broad rounded wings and a long tail, typically storyline, and says that Vincente Minelli aggressive or warlike policy, especially in foreign affairs (Oxford Advanced Learner's Dictionary) 
Like in the example above, the image of the bird is depicted in the dictionaries. Additional associations to support the image of this impressive bird are found in examples from the corpora. The dangerous and powerful character of the bird is visualised as the attacking potential of the destroyer named HAWK or as the defence arsenal of the patrol ship. The searching ability of the bird is shadowed in the former case and highlighted in the latter.

Naming ships after birds in American and British Navy discourse traditions is part of the common metaphorical ground of "exchange" of combat performance of seacraft and lifestyles of the animal world, in this case narrowed down to the slots of the frame BIRD.

Thus, metaphorical nomination of warships is directly influenced by the cognitive mechanisms of focusing/defocusing which spotlight animalistic characteristics that are later metaphorised. Consequently, these two mechanisms turn out to be dependent on the overall metaphorical context.

\section{CONCLUSION}

The study seeks to discover parallels between the two "riverbanks" - those of warships and animals - between which projections are "bridged" within the framework of conceptual metaphor. We sought to identify the patterns along which the animalistic conceptual metaphor is elaborated in British and American seacraft names, both official and unofficial (700 units). The most frequent elaborations of patterns of the SHIP IS A LIVING BEING metaphor turn out to be the following: SHIP IS AN ANIMAL/ A FISH/ AN INSECT/ A BIRD/ A FANTASTIC CREATURE.

In the process of mapping features from the source domain (LIVING BEING) on to the target domain (WARSHIP) there are typically characteristics loaded with information relevant in the eyes of the name-creator. These characteristics are the potential keepers of metaphorical images expressed in the conceptual metaphor SHIP IS A LIVING BEING. The choice is dictated by the aims of nomination and established by associations between the given domains.

The domain of animal world is literally a collection of basic and culturally loaded images of mammals, fish, birds, insects and the rest. The productivity of the animal domain as a source for seacraft naming is accounted for by its connotative value, various combinations of subjective and objective components. The vast collection of ship names gives an insight into the visualising of illustrative linguistic phenomena that are expressive, uniquely motivated, alias-like, stereotyped, and marked.

In addition to metaphor one more cognitive mechanism accounts for the choice and motivation of a warship name. It is the mechanism of de-/focusing of key characteristics of living beings to be profiled in secondary names. Despite the fact that nomination can be exclusively ingenious and artistic as it involves a play on attention focus when the chosen name intentionally broadens or narrows the scope of characteristics, the cognitive mechanisms of metaphor and de-/focusing guarantee the common motivational basis. Interestingly, visualisation of two objects (the ship and the animal) simultaneously enables us to trace not only one-directional mappings between domains, but sometimes an exchange of characteristics between the military field and the animal world. Thus, the ship "develops" animalistic characteristics, and the animal, in its turn, assumes a combative image as if portrayed in "khaki" style. Although this is a subject for further broader research, this exchange-factor seems to suggest "mutually beneficial partnership" between the given domains. 
Thus, underlying the naming process is the syncretic set of cognitive mechanisms that help construct the meaning of a secondary name. Metaphor can be a trigger for mappings between domains and the basis for new names' formation while being accompanied by stereotyping, focusing, defocusing and the like. Animalistic conceptual metaphor in artefact names is embodied as a range of instances of conformism and tradition. Still, the very names of artefacts, numerous as they are, illustrate the variability potential of conceptual metaphor as a tool of naming.

\section{REFERENCES}

1. Belyaevskaya, E. G. (2012). Frejm «politik» v angloyazychnom biograficheskom diskurse. [Frame "POLITICIAN" in the English biographical discourse] Politicheskaya lingvistika. № 2, 21 - 26. (in Russian).

2. Belyaevskaya, E. G. (2013). Konceptual'naya metafora kak istochnik stilisticheskih priemov v diskurse. [Conceptual metaphor as a source of stylistic devices in discourse] Voprosy kognitivnoj lingvistiki, №3 (36), 41 - 48. (in Russian).

3. Belyaevskaya, E. G. (2013). Frejmy «Dejstviya» i «Deyatel'nosti» kak osnovanie klassifikacii leksicheskih edinic. [Frames of "action" and "activity" as a classification scheme for lexical units] Vestnik MGLU. №20 (680), 18 - 28. (in Russian).

4. Boldyrev, N. N. (2013). Interpretacionnyj potencial konceptual'noj metafory. [Interpretational potential of conceptual metaphor] Kognitivnye issledovaniya yazyka: sbornik nauchnyh trudov / In V. Z. Dem’yankov (Eds.), Vyp. XV: Mekhanizmy yazykovoj kognicii, (pp. 12 - 21), Tambov. (in Russian).

5. Charniak, E. (1982). Context recognition in language comprehension. Strategies for natural language processing. Hillsdale (N.J.). L.: Erlbaum, 435 - 454.

6. Ermolovich, D. I. (2001). Imena sobstvennye na styke yazykov i kul'tur. [Proper names at the intersection of languages and cultures] M.: R. Valent. (in Russian).

7. Evans, V. (2010). The perceptual basis of spatial representation. In V. Evans., P. Chilton (Eds.) Language, Cognition and Space (pp. 21 - 48), London: Equinox Publishing Ltd.

8. Evans, V. (2013). Metaphor, lexical concepts and figurative meaning construction. Cognitive Semiotics, 2013, Bangor University. Retrieved from https://ru.b-ok.global/book/3257061/5f5313 (accessed: 11.02.2021).

9. Feyaerts, K. (2000). Refining the Inheritance Hypothesis: Interaction between metaphoric and metonymic hierarchies. In A. Barcelona (Eds.). Metaphor and Metonymy at the Crossroads. A Cognitive Perspective (pp. 58 - 78), Berlin. New York: Mouton de Gruyter.

10. Fillmore, Ch. (1976). Frame semantics and the nature of language. Annals of the New York Academy of Sciences: Conference on the Origin and Development of Language and Speech. Vol. 280, $20-32$.

11. Fillmore, Ch. (1985). Frames and the semantics of understanding. Quaderni di semantica. Vol. VI, № 2, $222-254$.

12. Finegan, E. (2011). Language: its structure and use. USA: Cengage Learn.

13. Gal'perin, I. R. (1981). Tekst kak ob"ekt lingvisticheskogo issledovaniya. [Text as an object of linguistic research] AN SSSR, In-t yazykoznaniya Moskva: Nauka. (in Russian).

14. Gibbs, R. W. (1996). What's cognitive about cognitive linguistics. In E. H. Casad (Eds.). Cognitive Linguistics in the Redwoods: The Expansion of a New Paradigm in Linguistics. (pp. 27 - 53), Berlin; New York: Mouton de Gruyter. 
15. Golubkova, E. E. (2011). Korpusnye dannye pri izuchenii semantiki slovosochetanij ustojchivogo haraktera. [Corpus data in the study of semantics of set phrases] Metody kognitivnogo analiza semantiki slova. M.: RGGU, 206 - 212. (in Russian).

16. Golubkova, E. E. (2020). Korpusno-kognitivnaya lingvistika: osnovnye tendencii v razvitii nauki. [Corpus studies in cognitive linguistics] In Golubkova, E.E. (2020) Korpusno-kognitivnaya lingvistika: osnovnye tendencii v razvitii nauki. (in Russian).

17. Goossens, L. \& Pauwels, P. \& Rudzka-Ostyn, B. \& Simon-Vandenbergen, A.-M. \& Vanparys, J. (1995). By Word Of Mouth. Metaphor, Metonymy and Linguistic Action in a Cognitive Perspective. Amsterdam, Philadelphia.

18. Hausman, C. R. (1989). Metaphor and Art. Interactionism and Reference in the Verbal and Nonverbal Arts, Cambridge University Press NY.

19. Indurkhya, B. (1992). Metaphor and Cognition: an Interactionist Approach, Dordrecht: Kluwer Academic Publ.

20. Iriskhanova, O. K. (2014). Igry fokusa v yazyke: semantika, sintaksis i pragmatika defokusirovani$y a$. [Focus games in language: semantics, syntax and pragmatics of defocusing] Moskva: Yazyki slavyanskoj kul'tury. Studia philologica. (in Russian).

21. Jackendoff, R. S. (1984). Sense and reference in a psychologically based semantics. Talking minds: the study of language in cognitive science. Cambridge (Mass.), 49 - 72.

22. Kalanov, N. A. (2020). Morskaya biblioteka. [Marine library] Retrieved from http://www.kalanov.ru/index.php?id=22 (accessed: 11 February 2021)

23. Kivileva, E. B. (2017). Mekhanizmy nominacii edinic voennoj tekhniki (na materiale nazvanij amerikanskih i britanskih korablej) [Nomination mechanisms of military equipment (based on the analysis of British and American warships' names]: (doctoral thesis). Moskovskij gosudarstvennyj lingvisticheskij universitet, Moscow, Russia. (in Russian).

24. Kövecses, Z. (2008). Conceptual metaphor theory. Some criticisms and alternative proposals. In Annual Review of Cognitive Linguistics 6, 168-184. doi 10.1075/arcl.6.08kov.

25. Kövecses, Z. (2010). Metaphor: A Practical Introduction. 2nd ed. Oxford: Oxford University Press.

26. Lakoff, G. \& Johnson, M. (1980). Metaphors we live by. University of Chicago Press.

27. Lakoff, G. (1993). The contemporary theory of metaphor. Metaphor and thought. Cambridge: Cambridge Press, $202-251$.

28. Lakoff, G. (1987). Women, fire, and dangerous things: What categories reveal about the mind. Chicago; L.: U. of Chicago, xvii.

29. Leezenberg, M. (1995). Contexts of Metaphorical, Semantic and Conceptual Aspects of Figurative Language Interpretation. Amsterdam.

30. Lisov, P. B. \& Solodun, N. P. (2014). Funkcional'no-stilisticheskie i pragmaticheskie harakteristiki angloyazychnogo voennogo diskursa. [Functional, stylistic and pragmatic characteristics of English military discourse] Materialy VI Mezhdunarodnoj studencheskoj elektronnoj nauchnoj konferencii «Studencheskij nauchnyj forum», Moscow, 2014. Retrieved from http://www.scienceforum.ru/2014/discus/543/2291 (accessed: 20 May, 2016) (in Russian).

31. Merleau-Ponty, M. (1967). The Structure of Behavior. Trans. by A. L. Fisher. Boston: Beacon Press, Middleton Murry J. Op. Cit.

32. Porokhnitskaya, L. V. (2014). Konceptual'nye osnovaniya evfemii v yazyke: na materiale anglijskogo, nemeckogo, francuzskogo, ispanskogo i ital'yanskogo yazykov [Conceptual grounds of euphemisms in English, German, French, Spanish and Italian languages]: Avtoref. Diss. doktora filologicheskih nauk: Moskovskij gosudarstvennyj lingvisticheskij universitet. Moscow. (in Russian). 
33. Rakova, M. (2003). The Extent of the Literal. Metaphor, Polysemy and Theories of Concepts. Houndmills. New York: Palgrave Macmillan.

34. Rodina, N. A. (2014). Sovremennye detskie i molodezhnye prozvishcha: strukturno-semanticheskij i funkcional'no-dinamicheskij aspekty [Contemporary childhood and youth nicknames: structural, semantic, functional, and dynamic aspects]: dissertaciya ... kandidata filologicheskih nauk: 10.02.01 / Rodina Nadezhda Andreevna. Mesto zashchity: Baltijskom universitete im. I.Kanta. Kaliningrad. (in Russian).

35. Romanov, A. A. (2000). Imya sobstvennoe v politike: yazyk vlasti i vlast'yazyka. [Common nouns in politics: the language of power and power of the language]. Tver': Liliya LTD. (in Russian).

36. Rosch, E. (1983). Prototype classification and logical classification: The two systems. In E. Scholnick (Eds.). New Trends in Cognitive Representation: Challenges to Piaget's Theory (pp. 73 - 86), Hillsdale, NJ: Lawrence Erlbaum Associates.

37. Smith, N. \& Hoffmann, S. \& Rayson, P. (2008). Corpus Tools and Methods, Today and Tomorrow: Incorporating Linguists' Manual Annotations. Literary and Linguistic Computing, 23 (2), 163 180.

38. Stefanowitsch, A. (2006). Words and their metaphors: A corpus-based approach. Trends in Linguistics Studies and Monographs, v. 171, $63-105$.

39. Suvorina, E. V. (2015). Ispol'zovanie kvalimetricheskih metodov v lingvokognitivnyh issledovaniyah. [The use of qualimetric methods in linguistic research] Nauchnye issledovaniya: ot teorii k praktike: materialy II Mezhdunar. nauch.-prakt. konf. Cheboksary, 2015. In O. N. Shirokov (Eds.). - Cheboksary: CNS «Interaktiv plyus», 219-221. (in Russian).

40. Taylor, J. (1995). Linguistic categorization: Prototypes in Linguistic Theory. Oxford. 